\title{
The USA's Role in Mediating the Cyprus Conflict: A Story of Success or Failure?
}

\author{
AYLİN GÜNEY* \\ Bilkent University, Ankara, Turkey
}

\begin{abstract}
This article is an attempt to assess the role played by the United States in the search for a solution to the Cyprus conflict both during and after the Cold War. The USA's role in mediating the Cyprus conflict during crisis episodes is crucial for understanding the evolution of this 48-year-old stalemate. It was the superpower politics and containment strategy during the Cold War years that determined the course of action in US crisis mediation and determined its success or failure. In the post-Cold War period, on the other hand, the success or failure of the USA's crisis mediation in Cyprus has been determined by the fact that it remained the sole hegemonic power in world politics. This article aims to sort out the implications of success and failure in the USA's role in mediating the crises of 1963, 1967, 1974 and 1998, to account for the variation in the outcomes and speculate on the possible US role to be played regarding a probable major crisis in 2004 when Cyprus joins the EU as a divided island.
\end{abstract}

Keywords conflict $\cdot$ crisis $\cdot$ Cyprus $\cdot$ mediation $\cdot$ United States

I

THE SUPERPOWERS HAVE BEEN QUITE INFLUENTIAL in mediating numerous international conflicts. Although mediation is often thought of within the normative context of conflict resolution, when superpowers are the mediators it is more useful to adopt a 'realist' framework, as proposed by Saadia Touval (1992). In this respect, mediation can be conceptualized as a foreign policy instrument, employed by states to serve their own interests. Such states assign high priority to considerations of security, power and the promotion of their own influence in international politics (Touval, 1992: 232). Ronald Fisher labels this type of mediation as power mediation, in contrast to pure mediation. Power mediation, which is likely to be employed by major powers such as the USA, adds the use of leverage through promised benefits or threatened punishments to a negotiated settlement of the crisis through reason, persuasion, the control of information and the formulation of alternatives (Fisher, 2001: 313; Bercovitch, 1977: 142). In the same vein, Jacob Bercovitch argues that 'large states often 
create the opportunity to mediate and use the mediation as a vehicle to protect or promote their own interests (Bercovitch, 1977: 142).

The underlying assumption of a mediation process is that the third party is involved in a direct or procedural effort to find a solution to a conflict along the lines of a compromise in which concessions are exchanged according to the needs and relative resources of each disputant (Richmond, 1998: 4). The success of the mediator is a result of the leverage it has, and this can take various forms. First, leverage can come from the parties' need for a solution that the mediator can provide; second, from susceptibility to the shifting weight that the mediator can apply; and, third, from the parties' interest in side payments that the mediator can either offer or withhold (Touval, 1992: 233). In addition, the legitimacy of the mediator in the eyes of the parties is of crucial importance. The mediator should be seen as impartial, acceptable to the disputants and deserving their trust (Bercovitch, 1977: 141).

This article aims to assess the role played by the USA in mediating the Cyprus conflict, with special regard to the crisis episodes during the Cold War (i.e. 1963, 1967 and 1974) and the post-Cold War period (1998 and possibly 2004). In doing so, it aims to categorize US mediation efforts in terms of success and failure, and to assess the implications of US mediation efforts upon the evolution of the Cyprus conflict into a stalemate.

\section{The USA and Crisis Mediation in Cyprus During the Cold War Period}

Great-power influence has been crucial in the birth and evolution of the Cyprus conflict. Cyprus has always been strategically important because of its location at the crossroads of three continents and the major routes connecting the West with the East; it is also the only island in the utmost southern corner of the Eastern Mediterranean (Joseph, 1997: 58). Cyprus is extremely close to the oil-rich regions of the Middle East and lies to the north of the Suez Canal. Therefore, it serves as a crucial land base for operations in those regions. The implications of the Cypriot identity-based conflict (Fisher, 2001: 307), seen in connection with the strategic significance of the island, were a major source of concern and involvement for the two superpowers (the USA and the USSR) throughout the Cold War years (Joseph, 1997: 58). However, Soviet involvement in the Cyprus conflict is beyond the scope of this article.

Prior to the Cold War, the USA was involved neither historically nor geopolitically with Cyprus since the island remained a British Crown Colony until the mid-1950s. The Cold War, however, shaped US strategic interests to a great extent. The increased US strategic concern with Cyprus was very 
much in line with the country's overall containment strategy proposed by George F. Kennan, which aimed at preventing the spread of communism, especially in regions that were strategically vital for US interests (Gaddis, 1982).

During the Cold War years, US policy towards Cyprus was based on four main goals that reflected the overall scope of US interests in the Eastern Mediterranean: (a) the Republic of Cyprus should develop political stability and join together with the UK, Greece and Turkey to form a solid bulwark against communism; (b) Cyprus should stress economic development, free democratic institutions and a pro-Western orientation; (c) the USA should enjoy unrestricted use of its existing communications facilities on the island; and (d) the British Sovereign Base Areas should remain inviolate and available to any Western nation for any purpose (Adams \& Cotrell, 1968: 56). Although the prospect of ethnic violence was present in US considerations in the early months of 1955 (Stefanidis, 1999: 199), the USA regarded Cyprus as falling mainly under the responsibility of the British. Therefore, the USA did not play as important a role as the UK in mediating the 1955 ethnic conflict that culminated in the establishment of the Republic of Cyprus and the 1960 Constitution that shaped the legal framework for the new state. It was not until the 1963 crisis that the USA became actively involved in crisismediation efforts regarding the Cyprus dispute.

\section{The 1963 Crisis and the 1964 Johnson Letter}

An outbreak of violence between the Greek and Turkish Cypriot communities on the island in 1963 led the USA to get involved in the Cyprus issue for the first time, since in George Ball's words 'Cyprus was merely one more step in Britain's painful shedding of empire, and London had no longer the will or the resources to preside over such a quarrel' (Ball, 1982: 340). As a result, the British government notified the USA on 25 January 1964 that US assistance was required to maintain peace in Cyprus. Even though the USA was not pleased with the prospect of a possible US involvement, it was obvious that, if further steps were not taken, Turkey would intervene as one of the guarantor powers, referring to the London and Zurich Agreements signed in 1959 between the UK, Turkey and Greece. This, of course, would escalate tensions, endanger stability and eventually threaten US interests in the region.

The continuous rise in support for the communist party, AKEL, and its front groups on the island and the establishment of the EOKA (National Organization of Cypriot Fighters) were deemed extremely important for the USA. While the EOKA carried out various acts of sabotage against British 
military targets with the aim of driving the British out of Cyprus (ByfordJones, 1959: 87), AKEL was one of the strongest communist parties in the non-communist world, and it was well represented in the parliament. It is also important to note that AKEL was always loyal to Moscow and never suffered a serious ideological split. In fact, the political supremacy of Archbishop Makarios in Cyprus was largely based on the constant support of AKEL (Joseph, 1997: 68). The USA was increasingly concerned about the growing Soviet presence in the area, since it became clear during the crisis that Makarios's ties with the nonaligned bloc and the USSR were getting stronger. Makarios repeatedly called for a Soviet military intervention in the event of a Turkish intervention. Each of these factors enhanced the fears of US officials and reinforced the image of Cyprus as the 'Mediterranean Cuba' (Coufoudakis, 1975: 114). In other words, US concern with Cyprus cannot be properly understood without taking into consideration the threat posed by AKEL to the US strategic interests described above. Indeed, as stated earlier, it was AKEL and its links to Makarios that were key factors for both the USA's perception of Makarios and US policy development towards Cyprus throughout the 1960s and up to 1974.

To reiterate, the main objective of US foreign policy towards Cyprus in early 1964 was to ensure, first, that the conflict between the indigenous Greek and Turkish communities did not become the cause of a larger war, and, second, that the protracted political disorder on the island was not paramount in the USA's bilateral relations with either Greece or Turkey (Adams \& Cotrell, 1968: 67). For the USA, these two countries were pivotal in the strategy of containment and the internal strength of NATO. Therefore, for the USA, restoring peace was essential in order to avert a Greek-Turkish war, to ensure that negotiations could proceed to settle matters once and for all and to eliminate a situation that could be exploited by the USSR.

However, the shuttle diplomacy of George Ball and Senator J. William Fulbright failed. Turkey decided to intervene in the island, and events culminated in the bitterly worded 'Johnson Letter' delivered to Turkish Prime Minister İsmet İnönü. In that letter, US President Lyndon B. Johnson strictly forbade the use of any US-supplied military equipment for intervention in Cyprus. The letter obliged İnönü to reply that 'we have upon your request, postponed our decision to exercise our right of action in Cyprus conferred to us by the Treaty of Guarantee' (Başak, 1998: 116).

The US pressure on Turkey created an unbalanced situation that was to the advantage of the Greek Cypriots and thus made the UN's task harder, as the Greeks interpreted US pressure upon Turkey as US support, and it seemed that any future Turkish threat would again face US pressure (Başak, 1998: 116). After the rejection of the Acheson Plan that established the basis of the negotiations under UN auspices, the USA decided to disengage and to leave the matter to the parties concerned. 
The Cyprus crisis of 1964 was a severe test for the USA, but it was passed from the US perspective since the primary objective of preventing a war between Greece and Turkey was achieved without the need to employ any US troops or financial resources (Adams \& Cotrell, 1968: 67). In this respect, the US mediation in the 1964 crisis can be regarded as successful, since the USA used its leverage against Turkey in the form of the Johnson Letter and averted a possible war involving the two allies and the USSR. However, averting a war did not mean that the crisis was resolved for good. The USA was not diplomatically successful in exerting its influence on the parties on the island owing to fear of a possible engagement by the USSR. Despite the efforts of the US representative to the UN, who defended the Zurich and London treaties and claimed that the three Western guarantor powers had a legitimate right to intervene in Cyprus jointly or unilaterally, the Cypriot president, with the backing of the USSR, did not seem to support this option. As a result, the conflict was carried to the UN, and Security Council Resolution 186 of 4 March 1964 called upon all states to refrain from interference in Cyprus. It also recommended the establishment of a UN peacekeeping force as well as the appointment of a UN mediator in the 'Republic of Cyprus' (Joseph, 1997: 64). The usage of the word 'Republic' would be the major source of contention between the two communities in the future. In addition, this was a crucial turning point in the history of Cyprus, since the issue was internationalized for the first time. This would mean indirect involvement of the USSR in Security Council resolutions regarding Cyprus in the future.

\section{The 1967 Crisis and the Shuttle Diplomacy of Cyrus Vance}

The resurgence of inter-communal fighting in Cyprus in 1967 was as serious as the events of 1964 . In response to the new crisis, Turkey immediately announced full mobilization of its troops in preparation for a possible intervention in Cyprus. In the meantime, the US ambassador was given an ultimatum by the Turkish government, implying that if the USA intervened to stop Turkey from coming to the aid of Turkish Cypriots, as it had in 1964, it would never be forgiven (Hart, 1990: 52). Soviet intervention in the crisis followed the same pattern as in 1964, but this time Greece - rather than Turkey - was the target of the Soviets. There were two reasons for this change: first, the Turco-Soviet rapprochement that began in the aftermath of the 1964 crisis as a result of the Demirel government's 'multi-faceted' foreign policy (Bölükbaşı, 1988: 119), and, second, the coup d'état in Greece by a USbacked anti-communist junta. The colonels in Greece were actively pursuing 
a policy of NATO-ization of the island through double enosis (union with Greece) (Joseph, 1997: 70).

The USA was again prepared to use as much diplomatic persuasion as possible to avoid a resort to arms by any side involved in the conflict. However, since it had intervened against Turkey diplomatically in the 1964 crisis in rather sharp terms, this time it opted to avoid doing anything that might further worsen its relations with the Turkish government, fearing that the latter would tilt further towards the USSR (Adams \& Cotrell, 1968: 72). As a result, Ambassador Hart and Turkish Foreign Minister İhsan Sabri Çağlayangil were able to sit together and produce a draft proposal of five points, whereby (1) the government of Turkey would reassert its commitment to the inviolability and integrity of the Republic of Cyprus; (2) all Greek and Turkish troops in excess of those permitted by the London-Zurich Treaties would be withdrawn; (3) the United Nations Peacekeeping Force in Cyprus (UNFICYP) would supervise these withdrawals and would collect arms from unauthorized civilians and militias; its role on the island would be greatly strengthened by an enlarged mandate from the UN, to enable it to keep the peace; the regular Cyprus police, now divided and deployed on confessional lines, would be reconstituted and strengthened as a mixed Greek-Turkish Cypriot force, to replace the irregular bands; (4) an indemnity would be paid to the Turkish Cypriot victims of Ayios Theodhoros and Kophinou; and (5) special security measures would be devised to protect Turkish Cypriot communities not protected by Cypriot police or the National Guard (Hart, 1990: 60-61).

Following these developments, the USA pursued 'quiet diplomacy' and kept open communication channels with the surrounded Turkish Cypriots and Dr Fazil Küçük, Vice-President of the Republic of Cyprus (Adams \& Cotrell, 1968: 73). It also decided to assign former deputy secretary of defence Cyrus Vance to the island. This was a clear sign of how much Cyprus mattered to the USA. Vance's assignment was intended to prevent the outbreak of war and the possibility that the USSR, which still had a sizeable presence in the Mediterranean following the Six Day War, could be dragged into the conflict. Thus started Vance's shuttle diplomacy. Vance successfully mediated between Greece and Turkey, and neither side walked away from the situation feeling humiliated - since the final settlement was imposed by the USA.

In mediating this crisis, superpower concerns were extremely important for the USA. This time, the leverage it used was against Greece, not Turkey. The long-term objective of removing Makarios was still there, and the USA did nothing to remove the junta in Greece since, in the USA's view, Greece was not regarded as being ready for democracy at the time. The pursuit of these short-term US interests would have important implications for the next crisis in 1974, which culminated in the de facto division of the island. 


\section{The 1974 Crisis and the Failure of US Mediation}

In the early 1970s, US policy towards Cyprus became increasingly focused on removing Makarios from power. This coincided to a great extent with the policy of the Greek junta, which staged a coup d'état against Makarios on 15 July 1974 and replaced him with Nikos G. Sampson, a vocal advocate of enosis.

The USA's initial response to the crisis triggered by the coup d'état - which Hitchens (1984: 79) claims the USA already knew about - reflected confusion on its part. To the surprise of the international community, the USA was alone in its refusal to explicitly condemn the coup and the insurgent regime in Nicosia (Bölükbaşı, 1988: 88). The US State Department took the position that the change of government in Cyprus was an 'accomplished fact' and that the prime objective of the USA was merely to 'prevent further exacerbation of the situation' by 'urging restraints on all concerned' (Cononi, 1996: 39). On the day of the coup, the State Department declared that US policy remained that of supporting the independence and territorial integrity of Cyprus and its constitutional arrangements, and it urged all other states to support a similar policy (Stern, 1977: 112). Moreover, the USA vetoed a UN Security Council draft resolution condemning Greece for the role it had played in the coup (Mirbagheri, 1998: 111). It was obvious that the coup seemed to fulfil the US policy objectives of dealing with the 'Makarios factor' (Mirbagheri, 1998: 111).

In discussing this controversial episode in Cyprus's history, Hitchens (1984: 69) argues that 'a peculiar symbiosis' emerged between the Greek junta and the USA. The junta wanted to 'do something about Cyprus that would vindicate its claim to have renewed Greek life and Greek pride' and had directly contributed money to the Nixon-Agnew election campaign in 1968 (Hitchens, 1984: 75). In return for its acquiescence, the USA would acquire a home port in Piraeus for its Sixth Fleet under junta auspices. In short, 'this symbiotic relationship involved arms sales, political favours and influence peddling' (Hitchens, 1984: 75), and 'the junta leader George Papadopoulos had been on the payroll of CIA since 1952' (Theophylactau, 1995: 106).

The novelty in this particular crisis was the lack of fear on the part of the USA with regard to possible Soviet involvement and a direct confrontation between the two superpowers. Nevertheless, other interests - such as the cohesion and strength of NATO and the political and strategic situation of the entire region - were still at stake. Once again, the USA's close relationship with Greece and Turkey and its concern for stability in the region led it to become involved in yet another crisis in Cyprus. This time, the primary threat for the USA was Turkey and the possibility that it might land troops 
on the island in an attempt to protect the rights of Turkish Cypriots in line with the principles of the 1960 settlement. And, as in the crises of 1963-64 and 1967, the USA's primary objective remained the prevention of a wider Greco-Turkish confrontation over Cyprus that could lead to a possible Soviet involvement.

US restraint vis-à-vis the Greek-led coup d'état was coupled with a policy of tolerance towards Turkey's landing troops on the island on 20 June 1974. US Secretary of State Henry Kissinger justified this policy by stating that 'only the threat of US military action could have prevented a Turkish landing on the island; that was an impossibility' (Joseph, 1997: 74). Indeed the USA's influence on Turkey was limited as a result of the entangled nature of US-Turkish relations at the time, and any forceful intervention would have pushed Turkey closer to the USSR (Joseph, 1997: 74). The Turkish card was therefore to be kept in reserve (Hitchens, 1984). However, the USA's restraint vis-à-vis Turkey infuriated the Greeks and Greek Cypriots, who organized mass demonstrations in Athens and Nicosia. Not coincidentally, the US ambassador in Cyprus, Roger Davies, was assassinated in Nicosia on 19 August 1974 (Mirbagheri, 1998: 112). As a result of pressure stemming from the Greek-American lobby, the USA initiated an arms embargo against Turkey. However, this policy lasted only a very short time and, other than worsening the US-Turkish relationship, achieved next to nothing.

The policy of containment, together with the importance of intra-alliance cohesion in NATO, dominated US policy and limited the USA's peacemaking ability in Cyprus during this period. Although the USA might have used its considerable influence over Greece and Turkey, and could possibly have precluded the events in 1974, it decided instead on a policy of 'constructive ambiguity' (Mirbagheri, 1998: 112). This had extremely important repercussions for the subsequent developments on the island that ended up in the division of the island that has lasted to today. In other words, this was the second turning point in the modern history of Cyprus: the failure of crisis mediation by the USA in 1974 contributed greatly to the Cyprus problem becoming an imbroglio (Dodd, 1998).

\section{The USA and the Cyprus Stalemate During the Post-Cold War Period}

The end of the Cold War, with the collapse and dismantling of the USSR and the Communist Bloc, brought about some important changes in the threat perceptions of the USA. The containment strategy of the USA was no longer relevant, since the communist threat had seemingly disappeared from the agenda and the USA remained the only hegemonic power. However, the end 
of the Cold War did not bring the end of power politics, and realism still remains the most useful theoretical framework for analysis. Other instabilities stemming from ethnic conflicts in the Balkans and crises in the Middle East - such as the invasion of Kuwait by Iraq and the subsequent Gulf War led by the USA - made it clear that the Mediterranean still mattered a lot for US strategic interests and that 'the US involvement in the Mediterranean is neither a transitory phenomenon flowing from the strategic requirements of the Cold War, nor is it new in historical terms' (Lesser, 1992: 3).

US strategic interests in the post-Cold War Mediterranean can be considered as both regional and global. The regional perspective usually centres on either Southern Europe or the Middle East, whereas the global one concerns general crisis management. In addition to the security of Israel, issues such as access to oil, migration and the proliferation of weapons of mass destruction in the possession of authoritarian states in the region, such as Iraq or Iran, have become vital concerns for US strategic interests (Holmes, 1995: 217). Indeed, this is the main justification for the post-Cold War military hegemony in the Mediterranean revealed by the existence of the US Sixth Fleet (Montagnon, 1998: 12-13). The USA also has strong national interests in the survival of Israel, a stake that has become particularly important since the Gulf War in 1991. As a result of these policy preferences, and owing to its special strategic location, Cyprus lost no weight in US policy formulations. On the contrary, it grew in importance since the USA regarded it as 'a valuable partner in the fight against the new global threats of proliferation, terror, illegal narcotics, and international crime' (Müftüler-Baç, 1999: 567), and in addition 'the two countries have shared values and a shared commitment to building a world based on open markets, democratic principles and the rule of law'. ${ }^{1}$ A peaceful solution to the Cyprus stalemate remained an important issue for successive US administrations that voiced a desire to be the 'catalyst' for a solution (Migdalowitz: 1996: 12).

\section{The S-300 Missile Crisis and US Mediation}

Almost a decade later, the USA's abilities in crisis mediation were put to the test once again when a new crisis erupted over the Greek-Cypriot government's announcement on 4 January 1997 that it would purchase S-300 (SA-10) anti-aircraft missiles with a 90-mile range from Russia. The GreekCypriot side announced that the missiles were for defensive purposes: to protect Greek Cypriots from further Turkish expansion in the future. In the

\footnotetext{
${ }^{1}$ See the press release by the US State Department in connection with Madeleine Albright's statement prior to her meeting with Cyprus's Foreign Minister Ioannis Kasoulides, Washington, DC, 6 June 1997.
} 
same vein, Russia declared that the S-300 contract was purely a commercial deal and that it could not be held responsible for the longstanding tensions on Cyprus. On 6 January, the US State Department expressed the view that the decision 'introduces a new and de-stabilising element' and that 'this new missile system threatens to take the arms build-up on Cyprus to a new and disturbing qualitative level .... It makes any mediation effort much more difficult. ${ }^{2}$ The USA was further alarmed when Turkish officials stated that they would not allow the weapons to be deployed on the island, threatening to attack Cyprus if necessary, and the State Department immediately declared that any use of force was unacceptable. US State Department spokesman Nicholas Burns declared that Turkey had no right to threaten Greece, but Carey Cavanaugh, Director of the Office of South European Affairs, toured the capitals of the involved countries to obtain an assurance that the missiles would not be delivered for another 16 months (Dodd, 1998: 99; Migdalowitz, 1997: 1).

On 20 January 1997, in retaliation against the Greek-Cypriot decision, Turkish President Suleyman Demirel and President of the Turkish Republic of Northern Cyprus (TRNC) Rauf Denktaş signed a joint defence declaration, stating that the reassurances by the Greek-Cypriot side that the missiles would not be deployed for some time was 'meaningless'. The two leaders added that any attack on the TRNC would be considered an attack on Turkey, and any further activity at Greek bases in southern Cyprus would be reciprocated by similar moves in the north. They also suggested that the Greek/Greek-Cypriot provocation was intended to escalate tension in order to lead to a reduction in Turkey's 1960 guarantees through the deployment of a multinational force, arguing that this 'would not be allowed' (Migdalowitz, 1997: 1).

From the USA's point of view, the deployment of the missiles would undermine the security of Cyprus and the missiles were regarded as 'effective enough to worry the Turks, but not effective enough to prevent a Turkish invasion' (Gordon: 1998). Moreover, the motive lying behind Russia's sale of the weapons was to extend its influence to the Mediterranean and to cause problems for NATO by encouraging tensions between Greece and Turkey, both members of the alliance. In addition, it seemed obvious that Russia was still interested in the region - maybe even more than it had been during the Cold War years. Even though the Russians declared that the sale was simply a commercial deal that would bring in some hard currency for Russia, this was too simple an explanation from the US viewpoint. Russia definitely had many strategic interests in the Eastern Mediterranean, as its strategic concept of 'near abroad' also revealed. First of all, Cyprus was a

2 US Department of State, Daily Press Briefing DPB \#3, Monday, 6 January 1997; reproduced at http:/ /www.fas.org/news/usa/1997/01/msg00005a.htm (12 December 2003). 
wonderful location for espionage interests, since it was at the intelligence crossroads of the Eastern Mediterranean. The instalment of the missiles would mean that numerous Soviet experts would be staying on the island indefinitely. Second, another part of Russia's strategic interest lay in extending Greek-Turkish tensions to the Balkans, in this way retaliating against NATO expansion by breaking apart the southern flank of the Alliance. Third, Cyprus was important for Russia with respect to money-laundering. Writing in the New York Times, William Saphire (1998) argued that 'Primakov would be able to monitor the flight of Russian rubles to foreign banks, and gain added leverage over Serbia, which gets clandestine foreign money support through Cyprus.'

Although the Cold War was over, this crisis revealed that the involvement of Russia in weapons sales to Greek Cypriots was quite alarming for the USA. Though using its leverage against the Greek Cypriots, the USA also tried its utmost not to offend them. For instance, Ambassador Tom Miller stated in a press conference that 'we do not think the missiles ... are a good idea in terms of helping us do our job as negotiators. This is not saying that the Republic of Cyprus doesn't have the right to make decisions about its defence needs. That is not what this is about. It complicates our efforts to serve the role that we are trying to serve. ${ }^{3}$ Although the Greek-Cypriot side ultimately gave in, the rising danger in the Eastern Mediterranean posed by Greek-Cypriot rearmament and the firm, sometimes belligerent, Turkish response undoubtedly played an important role in the USA's becoming more closely involved in the Cyprus issue and in its decision in June to appoint Richard Holbrooke - the architect of the Dayton Agreements - as President Clinton's Special Envoy to Cyprus with the goal of reaching a longlasting settlement.

\section{Cypriot Membership of the EU: A Lingering Crisis?}

The Republic of Cyprus - as represented only by the Greek Cypriots - signed its Accession Treaty with the European Union on 16 April 2003, and will become a full EU member on 1 May 2004. These events represent another major turning point in the history of the Cyprus conflict. The emergence of the issue of EU accession for Cyprus by 2004 has both complicated matters and offered some hope for the regionalization of some norms of cooperation and pluralism via supranationality in the following ways (Richmond, 2002: 127). First, unless a solution is reached before this date, Turkey will be con-

${ }^{3}$ Statements made by Special Cyprus Coordinator Thomas Miller during a Bicommunal press conference at the J. W. Fulbright Center in the Buffer Zone; reproduced in USIA Wireless File EUR 206, 10 March 1998, p. 29. 
sidered by the EU as a country that has invaded the territory of a memberstate. Second, although it has not yet appeared on the agenda of US-Turkish bilateral relations, Cyprus is likely to emerge as the biggest issue facing Turkey's relations with the West (Makovsky, 2001: 2).

There are two divergent views on the impact of EU membership upon the Cyprus problem. On the one hand, there are those who think that EU membership will have a 'catalytic effect' on the search for a solution to the Cyprus conflict (Diez, 2002: 140) According to Holbrooke, 'the prospect for membership of Cyprus in the EU has been the biggest new factor in the 30-year stalemate' (Brademas: 1997: 4). On the other hand, there are those who argue that EU membership will have a disruptive effect by undermining certain aspects, such as the bizonality or bicommunality of the settlement envisaged by UN resolutions (Richmond: 2002: 128).

However, with the entry of the 'EU factor' onto the Cyprus scene, Holbrooke's diplomatic efforts proved futile since one of the sine qua non conditions set forth by Denktaş for restarting negotiations was the withdrawal of the application to join the EU by the Republic of Cyprus and recognition of the legitimacy of the TRNC government by the Greek Cypriots (Sennett, 1998). At times, the position of the USA appeared contradictory. On the one hand, Holbrooke stated that if progress is to be made on Cyprus, both sides must be willing to engage in a genuine give-and-take. This is not the current situation, especially in regard to two positions taken by the Turkish side. ${ }^{4}$ On the other hand, he displayed an ambiguous stance regarding the EU application by the Republic of Cyprus as represented only by Greek Cypriots, admitting that it is very clear and no one has disputed that Glafcos Klerides does not represent or have control of the people of Northern Cyprus'. ${ }^{5}$

It is important to note that, for the USA, the most important actor in the EU-Turkey-Greece triangle seems to be Turkey, owing to its strategic location and its history as a reliable ally of the USA. Turkey stands at the nexus of three areas of increasing strategic importance, with regard to both energy and foreign policy for the United States and Europe: the Balkans, the Caspian region and the Middle East. The tension between Greece and Turkey over a rocky islet in the Aegean and the S-300 missile crisis indicated that Turkey could easily resort to arms when it was a matter of national interest. It appears that what is of vital interest for the USA is the stability of the region. Therefore, the USA did not oppose the accession of Cyprus to the EU, but it protested against the exclusion of Turkey from the process. The USA's sympathy towards Turkey could be seen in the aftermath of the Conclusions of the 1997 Luxembourg European Council, which constituted a 'slap in the

${ }^{4}$ The statements by Richard Holbrooke are reproduced at http://www.pio.gov.cy/news/dailynews/ news1998_5_4.htm (12 December 2003).

${ }^{5}$ Hürriyet, 5 May 1997. 
face' for Turkey. At Luxembourg, Turkey was not even listed among the candidate countries for membership to the EU, while accession negotiations with Cyprus were to begin in 1998. Having observed Turkey's resentment, the USA dispatched diplomats to foreign ministries all over Europe to make clear that the USA has been critical of the EU's decision to leave Turkey off its shortlist of candidates. The USA also tried to persuade the EU to take another look at Turkey's application. ${ }^{6}$ The influence exerted by the USA particularly on Greece - worked and through lifting its veto over the decision regarding Turkey's candidacy status at the 1999 Helsinki Summit, Greece later paved the way for Turkey's candidacy to the EU. These moves by the USA led to a considerable reduction in tension and Turkey's feelings of resentment.

However, in contrast to the Clinton administration's multilateral approach involving close US relations with the EU and advocacy of Turkey's EU aspirations, the approach of George W. Bush's administration has been marked by unilateralism and damaged relations with the EU on account of the war on Iraq. These factors have indirectly played an important role in the Cyprus problem. At the beginning of 2003, the two sides of the Atlantic diverged sharply when the Bush administration decided to launch a war against Saddam Hussein's regime, and the USA encountered serious difficulty in gaining support for this move. The tension between the USA and the EU has also had significant implications for Turkey, since attempts by Bush to pressure the EU member-states into giving Turkey an exact date for the start of accession negotiations at the 2002 Copenhagen European Council failed to produce the expected results, unlike the events in 1999. In addition, the war on Iraq has damaged US-Turkish relations, since Turkey refused to support the USA's military intervention, viewing it as illegitimate.

\section{Concluding Remarks}

This article has aimed to assess the USA's mediation role in the Cyprus conflict during the Cold War and post-Cold War periods, with a specific focus on crisis episodes. The crisis episodes reveal that US mediation in the Cyprus conflict should be understood as a foreign policy instrument, and should therefore be evaluated within a 'realist' framework. The USA seemed to succeed in mediating the 1967 and 1998 crises, yet it failed to some degree in 1963 when Makarios was able to internationalize the problem, and failed completely in 1974 when Cyprus was divided by a 'Green Line' after Turkey

${ }^{6}$ According to a report in Time magazine, 'France has publicly questioned the wisdom of admitting Cyprus before a settlement, but Greece is promising to block EU enlargement if Cyprus' application is not moved along'; see Time, 18 May 1998, p. 25. 
landed its troops on the island. These two failures, however, were extremely important in the evolution of the Cyprus conflict and contributed greatly to the present stalemate in Cyprus.

Although the recent historic decision by the TRNC and Turkey to lift restrictions on the free movement of Greek and Turkish Cypriots across the 'Green Line' is a positive though ambiguous novelty, it seems clear at present that both sides continue to stick to their positions and cannot easily reach an agreement, as revealed in the rejection of the Annan Plan(s). Therefore, unless progress is achieved, the post-2004 period may be marked by a possible crisis triggered by the accession of Cyprus to the EU as a divided island. This will certainly pose serious challenges for political stability in and around Cyprus owing to the status of the Turkish troops stationed on the north of the island.

US Ambassador to Athens Nicholas Burns has stated that 'President George W. Bush and Secretary of State Colin Powell have been personally interested in this problem'. ${ }^{7}$ He encourages the Cypriot accession to the EU followed by the accession of Turkey, ${ }^{8}$ since 'the prospect of membership would encourage the Turkish Cypriots to negotiate a solution', ${ }^{9}$ and he remains committed to the UN effort to find a just and lasting settlement to the Cyprus problem. ${ }^{10}$ In the USA's view, the basis of a solution to the problem is a bizonal, bicommunal federation, and it is possible to reach a settlement that addresses the legitimate concerns of both sides and promotes regional stability.$^{11}$ However, the US policy in Cyprus seems to have been affected by a redefinition of US interests as a result of the Bush administration's War on Iraq, since the war has had disruptive implications for US-EU and US-Turkish relations.

If future settlement talks are indefinitely suspended and the likelihood of a permanent division of the island increases, this would represent a 'sweeping breakdown' (Stilides, 2002: 1-2) in Turkish-Greek relations, which could lead to a possible disruption in NATO - with regional consequences to follow (Payne, 1998: 15). Though the current US administration's policy towards Cyprus seems to resemble the previous tripartite US policy of supporting (a) a solution in line with UN Resolutions, (b) Cyprus's membership of the EU and (c) Turkey's membership of the EU, the USA will be unable to mediate in a future crisis since the Bush administration seems to have neither the necessary leverage nor the requisite legitimacy - to say nothing of trust -

\footnotetext{
7 Cyprus Mail, 9 May 2001.

8 Press Conference with Special Presidential Envoy for Cyprus, Ambassador Alfred Moses, US Embassy, Ankara, 11 January 2001.

9 Ibid.

${ }^{10}$ See President Bush's June 24 letter to Congress on the situation in Cyprus (progress report covering April-May 2002).

11 Statement by Ambassador-Designate to Cyprus Michael Klosson, Senate Committee on Foreign Relations, 25 June 2002.
} 
in the eyes of the parties involved: the EU, Turkey and Greece. Therefore, it is highly probable that the USA will fail in any attempts it makes to mediate in any crisis that might arise as a result of the accession of Cyprus to the EU in 2004 as a divided island.

* Aylin Güney is Assistant Professor at the Department of Political Science and Public Administration, Bilkent University, Ankara. The author expresses special thanks to Associate Professor Meltem Müftüler-Baç, who provided valuable comments on the initial stages of the manuscript, and Dr Shannonine Caruana for proofreading.

\section{References}

Adams T. W. \& J. Alvin Cotrell, 1968. Cyprus Between East and West. Baltimore, MD: Johns Hopkins University Press.

Ball, George W., 1982. The Past Has Another Pattern. New York: W. W. Norton.

Başak, Cengiz, 1998. 'The Policies of the Major Powers Towards Cyprus Crisis and United Nations (UN) Operations in Cyprus (UNFICYP) Between the Years of 1964-1974', Foreign Policy 2: 108-133.

Bercovitch, Jacob, 1977. 'Mediation in International Conflict: An Overview of Theory, A Review of Practice', in William I. Zartman \& J. Lewis Rasmussen, eds, Peacemaking in International Conflict: Methods and Techniques. Washington, DC: United States Institute of Peace Press (125-153).

Bölükbaşı, Süha, 1988. Turkish-American Relations and Cyprus. Lanham, MD: University Press of America.

Brademas, John, 1997. 'The Cyprus Problem: USA Foreign Policy and the Congress', GreekAmerican, 18 October 1997; available at http://www.mjourney.com/news/ national/amcyp.htm (13 March 2003).

Cononi, Rachel, 1996. 'U.S. Relations with Greece and Turkey: How Effectively Has the United States Fulfilled its Role as "Mediator"?', unpublished term project. Bologna: Paul Nitze School of Advanced International Studies.

Coufoudakis, Van, 1975. 'United States Foreign Policy and the Cyprus Question: A Case Study in Cold War Foreign Policy', in Theodore A. Couloumbis \& Sallie M. Hicks, eds, USA Foreign Policy Toward Greece and Cyprus: The Clash of Principle and Pragmatism, Conference Proceedings. Washington, DC: Center for Mediterranean Studies/American Hellenic Institute (110-126).

Diez, Thomas, 2002. 'Last Exit to Paradise? The European Union, the Cyprus Conflict and the Problematic "Catalytic Effect"', in Thomas Diez, ed., The European Union and the Cyprus Conflict: Modern Conflict, Postmodern Union. Manchester \& New York: Manchester University Press (139-162).

Dodd, Clement H., 1998. The Cyprus Imbroglio. Huntingdon: Eothen.

Fisher, Ronald, 2001. 'Cyprus: The Failure of Mediation and the Escalation of an IdentityBased Conflict to an Adversarial Impasse', Journal of Peace Research 38(3): 307-326.

Gaddis, John Lewis, 1982. Strategies of Containment: A Critical Appraisal of Postwar American National Security Policy. New York: Oxford University Press.

Gordon, Michael, 1998. 'Greek Cypriots To Get Missiles From Russians', New York Times, 29 April.

Hart, Parker T., 1990. Two NATO Allies at the Threshold of War: Cyprus, a Firsthand Account of Crisis Management, 1965-1968. Durham, NC: Duke University Press. 
Hitchens, Christopher, 1984. Cyprus. London: Quartet.

Holmes, John W., 1995. 'U.S. Interests and Policy Options', in John W. Holmes, ed., Maelstrom: The United States, Southern Europe and the Challenges in the Mediterranean. Cambridge, MA: World Peace Foundation (213-233).

Joseph, Joseph S., 1997. Ethnic Conflict and International Politics: From Independence to the Threshold of the European Union. London: Macmillan.

Lesser, Ian O., 1992. Mediterranean Security: New Perspectives and Implications for U.S. Policy. Santa Monica, CA: RAND.

Makovsy, Alan, 2001. 'Turkey and the Bush Administration: The Question Marks', Policy Watch No: 527. Washington, DC: Washington Institute for Near East Policy.

Migdalowitz, Carol, 1996. 'Cyprus: Status of U. N. Negotiations', CRS Issue Brief for Congress, 3 December 1996; available at http:/ / www.fas.org/man/crs/89-140.htm (12 December 2003).

Migdalowitz, Carol, 1997. 'Cyprus: Status of U.N. Negotiations', CRS Issue Brief for Congress, 30 January 1997 (1-15).

Mirbagheri, Farid, 1998. Cyprus and International Peacemaking. London: Hurst.

Montagnon, Anne, 1998. 'The Mediterranean Between the European Union and the United States: A New Competition Area?', paper presented at the summer school on 'The Mediterranean and the New International Order', Center for Mediterranean Studies, University of Catania, 5-12 July 1998.

Müftüler-Baç, Meltem, 1999. 'The Cyprus Debacle: What the Future Holds', Futures 31(6): 559-575.

Payne, Douglas, 1998. 'The Cyprus Problem: A Need to Defend Principles', Mediterranean Quarterly 9(2): 9-15.

Richmond, Oliver P., 1998. Mediating in Cyprus: The Cypriot Communities and the United Nations. London: Frank Cass.

Richmond, Oliver P., 2002. 'The Multiple Dimensions of International Peacemaking: UN and EU Involvement in the Cyprus Conflict', in Thomas Diez, ed., The European Union and the Cyprus Conflict: Modern Conflict, Postmodern Union. Manchester \& New York: Manchester University Press (117-136).

Saphire, William, 1998. 'Primakov in Cyprus', New York Times, 2 July.

Sennett, Charles M., 1998. 'In Cyprus, Old Hatreds, New Threats', Boston Globe (reproduced in USAIA Wireless File EFS 210, 5 May).

Stefanidis, Ioannis D., 1999. Isle of Discord: Nationalism, Imperialism and the Making of the Cyprus Problem. London: Hurst.

Stern, Lawrence, 1977. The Wrong Horse. New York: Times Books.

Stilides, John, 2002. 'A Cyprus Settlement: Pulling NATO into the 21st Century', Strategic Regional Report of the Western Policy Center, May 2002; available at http://www. westernpolicy.org/SRR/IT-7-5.asp (12 December 2003).

Theophylactau, Demetrios A., 1995. Security, Identity and Nation-Building: Cyprus and the European Union in Comparative Perspective. Aldershot: Avebury.

Touval, Saadia, 1992. 'The Superpowers as Mediators', in Jacob Bercovitch \& Jeffrey Z. Rubin, eds, Mediation in International Relations. New York: St. Martin's (232-248). 